\title{
Servant Leadership Improves the Knowledge Sharing Behavior of Employees in Organization: A Case of Higher Education Sector in Pakistan
}

\author{
Hina Amin', Farhan Ahmed ${ }^{2}$, Riaz Hussain Soomro ${ }^{3}$
}

\begin{abstract}
The purpose of this paper is to investigate the role of servant leadership in organizations in Karachi and to investigate the level of knowledge sharing (KS) behavior among employees. The study based on quantitative design and the primary data has collected from the higher education sector through a survey questionnaire. Furthermore, multiple regressions have used for model testing. The findings of the study-enlightened benefits of knowledge sharing behavior that can be prevailed through a servant leadership model and encourage employees' participation. Four traits of servant leadership that are altruistic calling, emotional healing, and organizational stewardship have a positive impact on knowledge sharing behavior of employees. The findings of the study will be beneficial for the employees of the organization to understand the importance of servant leadership and its application in enterprises.
\end{abstract}

Keywords: servant leadership, knowledge sharing, employees' behavior

JEL Classification: J59, M19, M54

\begin{abstract}
Abstrak. Tujuan dari penelitian ini adalah untuk menyelidiki peran kepemimpinan pelayan dalam organisasi di Karachi dan untuk menyelidiki tingkat perilaku berbagi pengetahuan (KS) di antara karyawan. Penelitian ini didasarkan pada desain kuantitatif dan data primer telah dikumpulkan dari sektor pendidikan tinggi melalui kuesioner survei lebih lanjut, teknik regresi berganda telah digunakan untuk pengujian model. Temuan penelitian-manfaat terungkap perilaku berbagi pengetahuan yang dapat diatasi melalui model kepemimpinan yang melayani dan mendorong partisipasi karyawan. Empat sifat kepemimpinan pelayan yang panggilan altruistik, penyembuhan emosional dan pelayanan organisasi memiliki dampak positif pada perilaku berbagi pengetahuan karyawan. Temuan penelitian ini akan bermanfaat bagi karyawan organisasi untuk memahami pentingnya kepemimpinan pelayan \& penerapannya di perusahaan.
\end{abstract}

Kata Kunci: kepemimpinan pelayan, berbagi pengetahuan, prilaku karyawan

\section{How to Cite:}

Amin, H., Ahmed, F., \& Soomro, R. H. (2019). Servant Leadership Improves the Knowledge Sharing Behavior of Employees in Organization: A Case of Higher Education Sector in Pakistan. Etikonomi: Jurnal Ekonomi. Vol. 18 (1): 83 - 92. doi: http//dx.doi.org/10.15408/etk.v18i1.6190. 


\section{Introduction}

The interest of academicians/practitioners is growing in the leadership field. Servant leadership is the concept that has evolved in recent past and was found to be successful in some organizations worldwide where leaders share knowledge and work together with subordinates as a team leader cum polite player. Besides that organization's concern now a day is to produce better knowledge and transform this knowledge into meaningful form; more and more researches are performing by practitioners and academicians to understand the phenomenon of servant leadership and knowledge sharing behavior in the organization.

Knowledge is critical for any organization and its employees that provide a sustainable competitive advantage in the dynamic arena (Foss \& Pedersen, 2002). It has also observed that organizations' survival is not just for providing goods and services to their customers but also create a knowledge-intensive environment for the employees to bring innovation and uniqueness that will enhance the confidence level of employees. The culture of the organization is crucial for promoting knowledge sharing environment, and one of the most critical factors for organizational culture is leadership. Greenleaf (1977) has proposed the servant leadership model, and this model appropriately fit with the organization that strongly consider the empowerment of employees and encourage their participation. The servant leader works as a servant to their subordinates and intends to satisfy the needs of others (Russell \& Stone, 2002). Servant leadership defined as, "Keep away oneself from using power, influence, and position to serve self instead inkling to a situation where these things are used to enable and encourage those who are under one's range of influence (Nwogu, 2004).

The purpose of this paper is to investigate the role of servant leadership in the organization to promote knowledge sharing (KS) behavior among employees by exploring the critical qualities of servant leadership that extracted from the literature and relate each condition with KS tendency. The research objectives that attained through this research study are: first, to determine the impact of altruistic calling (selfless) trait and knowledge sharing behavior of employees. Second, to examine the effects of emotional healing trait and knowledge sharing conduct of employees. Third, this study is going to investigate the impact of wisdom (wiseness) on knowledge sharing behavior of employees. Fourth, this study will consider the effect of persuasion on knowledge sharing behavior of employees. Finally, this study examines the impact of organizational stewardship on knowledge sharing behavior of employees.

This research study is just a small attempt to review the literature of servant leadership (traits of servant leadership) and knowledge sharing behavior. Employees under the supervision of good leaders have a motivational tendency to give their suggestions confidently (Avey et al., 2012). Besides that, the employees will help their colleagues/peers in completing their tasks and have a passion for their work (Kalshoven et al., 2013). While, the purpose of knowledge sharing in the organization is to exploit existing knowledge in a better way; knowledge sharing is a technique which is about identifying recent accessible knowledge to transfer and apply that knowledge for the solution of a particular problem in a better and faster manner relatively than other techniques (Christensen, 2007). These variables together are necessary for the improvement of organizational productivity. The 
area of servant leadership is still unexplored, and literature has contained minimal work on the relationship of variables mentioned above, the study narrows this gap by offering a unique framework for the organization also teaches managers that servant leadership attitude will encourage employees to share the knowledge and work in a positive environment. The concept of leadership remains esoteric although they have been studied for several years (Gupta et al., 2005). The range of leadership theories from trait to behavioral has still the capacity to explore and need to elucidate vigorously. Leadership is the relationship between influencer and a person who is influencing (Melchar \& Bosco, 2010).

Progress should do in the area of servant leadership; research studies should work out for further theoretical development (Melchar \& Bosco, 2010). Sendjay (2003) indicated that the phenomena of servant leadership demand in depth quantitative and qualitative researches to fill the gap and rationalize the various sub concepts, measurement scales and operationalization of the variables is next step to be made in this area. Multiple areas and variables in different organizations should explore; various combinations of research variables will help to enhance the literature contribution positively (Brewer, 2010). Wang \& Noe (2010) suggested that the relationship between knowledge sharing behaviors with environmental factors like leadership characteristics in an organization need to search. There is always confusion to understand that what servant leadership is all about this area is still need to explore, highlighted few distinct approaches to understanding this topic while considering all styles (Van Meter et al., 2016)

\section{Methods}

This research is quantitative, the collection of data has done in numerical form the analysis is followed by the causal way purely, and the purpose of the study is useful and tested. The time horizon of the research study is cross-sectional that involves the analysis of the population or subset at one specific point of time, the research choice is monomethod. The unit of analysis was employees in the higher education sector in Karachi Pakistan. Convenient and snowball sampling techniques used in this study, this paper covered theoretical and empirical aspects of the topic for more thorough analysis and to extract more useful knowledge that will contribute practically/academically and enhance the productivity of employees.

The philosophical paradigm of the study was posted positivism while deductive approach was used to get the specific result from the generalize concept about servant leadership and its role for enhancing knowledge sharing behavior among the employees. The population of the study was the employees of the higher education sector in Karachi especially business universities including faculty members and employees of different departments. The sample took from leading universities: SZABIST, IQRA, KASBIT and University of Karachi, estimated the size of the population were around 1000 to 2000 and sample size derived for this population from Parker and Rea table were 385 approximately while the respondent rate of this research was $52.4 \%$. The technique used in this research for data collections is primary data and secondary data analysis. Primary data collected through a survey questionnaire from the respondents and secondary data has taken from related articles and journals. 
The scale of the questionnaire as adapted from the literature after thorough analysis. The items of altruistic calling, wisdom, persuasive mapping, emotional healing, and organizational stewardship are based on a 5-point Likert scale (1 strongly disagreed to 5 strongly agree), which measures the degree to which the individual agrees with the described statement (Krekeler, 2010), while to assess the knowledge sharing behavior, scale taken from Chennamaneni (2007) studies. Responses were acknowledged on a 7 point Likert scale: 1 "Very infrequently" to 3 "Moderate Frequency (Few Times per month)" to 5 "Very Frequently (Many times daily)." To enhance the reliability and validity of findings Cronbach alpha reliability test has used and field experts have validated scales, however, the model has been testing by using regression analysis. Following is the regression equation of the model:

$$
K S B_{i}=\alpha+\beta_{1} A C_{i}+\beta_{2} E H_{i}+\beta_{3} W_{i}+\beta_{4} P M_{i}+\beta_{5} O S_{i}+\varepsilon_{i}
$$

Whereas, KSB is knowledge sharing behavior, AC is altruistic calling, $\mathrm{EH}$ is emotional healing, $\mathrm{W}$ is wisdom, PM is persuasive mapping and OS is organizational stewardship

\section{Result and Discussion}

The focus of this entire study was to check the servant leadership model with the relationship of knowledge sharing behavior that has never tested in the Pakistani context. In this study, the authors have tried to get the opinion of managers. Demographic factors discussed in Table 1, and it has exhibited that majority of the respondents were male and graduated.

Table 1. Demography of the Respondents

\begin{tabular}{ll}
\hline \multirow{2}{*}{ Gender } & Male 120 \\
& Female 83 \\
\hline Education & Majority of the respondents were graduate and experienced more than 1 year. \\
\hline Status & Mostly respondents were married \\
\hline
\end{tabular}

In Table 2, the Cronbach's alpha values summarized. This value tells the inter-item consistency or in other words the reliability of the scale Overall the result is reliable as per the criteria mentioned in various literature as this value must be in between 0.6 to 0.8 that shows the consistency in the responses.

Table 2. Reliability Analysis

\begin{tabular}{lcc}
\hline Variables & No of Items/Questions & Cronbach Alpha \\
\hline Altruistic calling (AC) & 4 & 0.71 \\
Emotional healing (EH) & 4 & 0.77 \\
Wisdom (W) & 4 & 0.64 \\
Persuasive mapping (PM) & 4 & 0.81 \\
Organizational stewardship (OS) & 4 & 0.70 \\
Knowledge sharing behavior (KSB) & 7 & 0.72 \\
\hline
\end{tabular}


The results of multiple regression analysis in Table 3 depicted that the overall model shows that there is $53.6 \%$ ( $\mathrm{r}$ square) variation on knowledge sharing behavior because of altruistic calling, emotional healing, wisdom, persuasive mapping, and organizational stewardship. The adjusted $\mathrm{r}$ square $53.2 \%$ indicating that there is modest predictability in this model and the comparison of $r$ square and adjusted $r$ square shows that adjusted $r$ square reduces the overall proportion of variation of knowledge sharing behavior. The results show that statistically there is an impact of altruistic calling $(\mathrm{t}=2.925)$, emotional healing $(\mathrm{t}=$ 6.125), persuasive mapping (2.413) and organizational stewardship (4.11) on knowledge sharing behavior of employees. Statistically, we can conclude that overall the model is fit, but the trait of having wisdom in leader does not have an impact on knowledge sharing behavior of employees while rest of the variables have influenced on enhancing knowledge sharing behavior tendency in employees of the organization specifically in the education sector of Pakistan.

Table 3. Regression Analysis

\begin{tabular}{lccc}
\hline Variables & B & t value & Sig \\
\hline Constant & 0.434 & 3.089 & 0.002 \\
Altruistic Calling & 0.201 & 2.925 & 0.004 \\
Emotional healing & 0.364 & 6.125 & 0.000 \\
Wisdom & 0.115 & 1.790 & 0.753 \\
Persuasive mapping & 0.188 & 2.413 & 0.013 \\
Organizational stewardship & 0.294 & 4.110 & 0.000 \\
\hline
\end{tabular}

The regression equation of the model that has derived after the analysis of data is given below:

$$
K S B=0.434+0.201(A C)+0.364(E H)+0.115(W)+0.188(P M)+0.294(O S)
$$

Whereas, $\mathrm{KSB}$ is knowledge sharing behavior, $\mathrm{AC}$ is altruistic calling, $\mathrm{EH}$ is emotional healing, $\mathrm{W}$ is wisdom, PM is persuasive mapping and OS is organizational stewardship.

One of the research indicated that servant leadership plays a vital role in developing trust among the employees (Shahzad et al., 2013). This study also encourages employees by using altruistic calling, emotional healing that how you show empathy to your employees, persuasive mapping (the way you persuade your employees) and organizational stewardship traits to share knowledge and help each other without any return just for the sake of betterment of the organization.

Leadership is a critical component to maintain a competitive edge and achieving a desirable outcome (Chien, 2004). No one can deny the importance of great leaders who facilitate their employees/subordinate with empowerment by providing them training (Spencer, 2007). However, the provision of sufficient training and resources to assistants, sharing information with them, ensure the excellent working conditions and explain what expected from the employees in terms of their performance related with the empowerment 
that is one of the dimensions of quality leadership (Jabnoun \& Al-Ghasyah, 2005). This result suggested that there is a need for servant leadership in the higher education sector of Pakistan to promote a better environment for sharing knowledge and have supportive behavior among colleagues.

Many organizations find knowledge sharing is essential to achieve sustainable competitive advantage (Gold et al., 2001; Chennamaneni, 2007). Multiple technologies encourage knowledge sharing behavior among employees in the workplace. Some techniques $\&$ tools are prevailed to support knowledge sharing contain Groupware, Intranets, Emails, E-learning (interactive system for learning), Knowledge repository, video conferencing, etc. (Chennamaneni, 2007). Knowledge sharing is the process of distribution \& exchange of knowledge throughout the organization (Alavi \& Leidner, 2001). Literature has identified certain factors that affect knowledge sharing behaviors of people (Hall, 2001). It has categorized into hard factors like tools/ technological apps (Alavi \& Leidner, 2001), and also soft factors such as personal motivation, culture (Hall, 2001), culture, value, trust (Lee \& Choi, 2003; Smith \& Rayment, 2007), resources e.g. time $\&$ environment (Hinds \& Pfeffer, 2003). Many people believe that best leaders are charismatic, strong presence, visionary and passionate but unfortunately these traits are absent in all high performing companies leaders, the people who possessed these traits are called servant leaders. The personal motivation suggested by Hall (2001) can consider as the role of servant leaders in the education of Pakistan who supports and motivates the employees including peers, subordinates, etc. to work with cooperation and share knowledge without having the threat of any insecurity.

Social learning theory is critical to mention here because it provides a theoretical basis for understanding the knowledge sharing phenomena (Bandura \& Walters, 1977). Employees who show the behavior of knowledge sharing are appreciated and rewarded by a leader, and then gradually they develop the understanding that knowledge sharing behavior is essential in organization that employees share knowledge and exchange constructive ideas, enhance the learning. Thus, the findings of the study have proven that the behavior of the leader at the workplace matters in social learning and encourage them to learn more and share more.

Leader-member exchange theory is defined as the quality of exchange (skills, knowledge, etc.) between a leader and an employee (Liden et al., 1997; Liden et al., 2008). Leaders should form quality social exchange that based on informal communication, trust, knowledge sharing and good relationship with followers; however, with others (beyond employment contract) don't form such kind of relationships. LMX theory constitutes both social exchange and trust perspective that will impact on employees' performance furthermore employees perceived that these kinds of leaders would work for the interest of their employees and remain loyal, supported and committed to them (Walumbwa et al., 2011; Martin et al., 2016).

Altogether, the findings of the study have shown statistically, theoretical and practically significant. However, the relationship in the model is tested the first time but has supported by various theories in connection of servant leadership with learning and sharing pattern of employees at the workplace. This study reviewed the impact of servant leadership on knowledge sharing behavior in the higher education sector of Karachi Pakistan. Leadership has always been highlighted topic concerning the workplace. When it is about the servant 
leadership theory emphasized by researchers, become stronger because this theory focused on style, behavior, and skills of the leaders. The review of the whole literature identified the gap that there is no research yet confirmed the relationship between servant leadership and knowledge sharing behavior. This framework established a unique relationship that will be helpful for the stakeholders to get the best output from the findings of this work.

The focus of servant leaders should be on: to serve, ethical, sympathetic and empowering behaviors while working with subordinates/followers. Especially at the workplace when followers feel supported, empowered and the relationship between leader and follower filled with trustworthiness than it surely helps the employees to reach them at their full potential that is what the underlying philosophy of this style. Servant leaders don't waste much time deciding to whom to give, how much and in what order. They give everyone in their organizations as they treat everyone equal. Managers should understand certain things about the workplace. They should avoid discrimination, and they provide open space for their employees so they can perform well, managers should own their organization always decide on purely merit basis so it will encourage employees and work with more spirit and share knowledge on the latest trends and working pattern.

\section{Conclusion}

The overall results were positive, but one hypothesis was failed to reject the null hypotheses this suggested that having wisdom in leader do not matter to promote and encourage knowledge sharing behavior in the organization. This study also concludes that servant leaders are more impartial and inclined towards justice to deal with employees so this will make them more motivated and they work more efficiently. As respondents came from the education sector, they required behavior that encouraged their professional learning that can be only possible when the manager/ supervisor/leader can understand others, work for others and persuasive skills. It is recommended that leaders should develop a good relationship and social exchange with employees and therefore with the evidence of this study it prove that servant leadership is instrumental in promoting information, knowledge and social exchange that will also make people more confident and competent.

The study has some limitations which represent the directions for future research, different authors have identified other variables of servant leadership which are responsible morality, covenantal relationship, transformational influence, spirituality, etc. moreover there are other sectors in Pakistan as well which can be explored to identify a conceptual framework of this research. Further empirical discussion can be done on this servant leadership while analyzing it with the motivation of high performing individuals at the workplace and organizational performance for subsequent quantitative researches. Another direction would be the calculation of predictive and concurrent validity to further clarify the relationship between servant leadership trait and knowledge sharing behavior in an organization. It is vital to explore the open area in this domain for the better use of leadership style not only favorable for employees but the organization as well. 


\section{References}

Alavi, M., \& Leidner, D. E. (2001). Review: Knowledge Management and Knowledge Management Systems: Conceptual Foundations and Research Issues. MIS Quarterly, 25(1), 107-136. https://doi.org/10.2307/3250961

Avey, J. B., Wernshing, T. S., \& Palanski, M. E. (2012). Exploring the Process of Ethical Leadership: The Mediating Role of Employee Voice and Psychological Ownership. Journal of Business Ethics, 107(1), 21-34. https://doi.org/10.1007/s10551-012$1298-2$

Bandura, A., \& Walters, R. H. (1977). Social Learning Theory. New Jersey: Pearson Education.

Brewer, C. (2010). Servant Leadership: A Review of Literature. Online Journal for Workforce Education and Development, 4(2), 1-8.

Chennamaneni, A. (2007). Determinants of Knowledge Sharing Behaviors: Developing and Testing an Integrated Theoretical Model. (Unpublished Thesis). Texas: University of Texas.

Chien, M. H. (2004). A Study to Improve Organizational Performance: A View from SHRM. Journal of American Academy of Business, 4(1/2), 289-291.

Christensen, P. (2007). Knowledge Sharing: Moving Away from The Obsession with Best Practices. Journal of Knowledge Management, 11(1), 36-47. https://doi. org/10.1108/13673270710728222

Foss, N. J., \& Pedersen, T. (2002). Transferring Knowledge in MNCs: The Role of Sources of Subsidiary Knowledge and Organizational Context. Journal of International Management, 8(1), 49-67. https://doi.org/10.1016/S1075-4253(01)00054-0

Gold, A. H., Malhotra, A., \& Segars, A. H. (2001). Knowledge Management: an Organizational Capabilities Perspective. Journal of Management Information Systems, 18(1), 185-214. https://doi.org/10.1080/07421222.2001.11045669

Greenleaf, R. K. (1977). Servant Leadership. New York: Paulist Press.

Gupta, A., McDaniel, J. C., \& Herath, S. K. (2005). Quality Management in Service Firms: Sustaining Structures of Total Quality Service. Managing Service Quality: An International Journal, 15(4), 389-402. https://doi.org/10.1108/09604520510606853

Hall, H. (2001). Social Exchange for Knowledge Exchange. In International Conference on Managing Knowledge: Conversations and Critiques. University of Leicester Management Centre.

Hinds, P. J., \& Pfeffer, J. (2003). Why Organizations Don't "Know What They Know": Cognitive and Motivational Factors Affecting the Transfer of Expertise. In M. Ackerman, V. Pipek, \& V. Wulf (Eds.), Sharing Expertise: Beyond Knowledge Management, (pp. 3-26). Cambridge: MIT Press.

Jabnoun, N., \& Al-Ghasyah, H. A. (2005). Leadership Styles Supporting ISO 9000: 2000. The Quality Management Journal, 12(1), 21-29. https://doi.org/10.1080/10686967.2005.1 1919236 
Kalshoven, K., Den Hartog, D. N., \& de Hoogh, A. H. (2013). Ethical Leadership and Followers' Helping and Initiative: The Role of Demonstrated Responsibility and Job Autonomy. European Journal of Work and Organizational Psychology, 22(2), 165-181. https://doi.org/10.1080/1359432X2011.640773

Krekeler, L. A. (2010). The Relationship between Servant Leadership Behavior and Individual Personality Style in New York. New Jersey: Seton Hall University.

Lee, H., \& Choi, B. (2003). Knowledge Management Enablers, Processes, and Organizational Performance: An Integrative View and Empirical Examination. Journal of Management Information Systems, 20(1), 179-228. https://doi.org/10.1080/07421222.2003.11045756

Liden, R. C., Sparrowe, R. T., \& Wayne, S. J. (1997). Leader-Member Exchange Theory: The Past and Potential for the Future. Research in Personnel and Human Resources Management, 15, 47-119.

Liden, R. C., Wayne, S. J., Zhao, H., \& Henderson, D. (2008). Servant Leadership: Development of a Multidimensional Measure and Multi-level Assessment. The Leadership Quarterly, 19(2), 161-177. https://doi.org/10.1016/j.leaqua.2008.01.006

Martin, R., Guillaume, Y., Thomas, G., Lee, A., \& Epitropaki, O. (2016). Leader-Member Exchange (LMX) and Performance: a Meta-Analytic Review. Personnel Psychology, 69(1), 67-121. https://doi.org/10.1111/peps.12100

Melchar, D. E., \& Bosco, S. M. (2010). Achieving High Organization Performance Through Servant Leadership. Journal of Business Inquiry: Research, Education, and Application, 9 (1), 74-88.

Nwogu, O. (2004). The Role of Follower Self-esteem, Emotional Intelligence and Attributions on Organizational Effectiveness. In The 2004 Proceedings of the Servant Leadership Roundtable. Regent University.

Russell, R. F., \& Stone, A. G. (2002). A Review of Servant Leadership Attributes: Developing a Practical Model. Leadership \& Organization Development Journal, 23(3), 145-157. https://doi.org/10.1108/014377730210424

Sendjay, S. (2003). Development and Validation of Servant Leadership Behavior Scale. In Proceeding of Servant Leadership Research Roundtable.

Shahzad, R., Rizvi, R. A., Waheed, A., Khan, I., Usman, S. M., Nazier, N., \& Kiyani, T. M. (2013). Linking Servant Leadership with Organizational Citizenship Behavior Through Trust: an Embryonic Structural Modeling Approach. European Journal of Social Sciences, 39(2), 273-284.

Smith, J. A., \& Rayment, J. J. (2007). The Global SMP Fitness Framework: A Guide for Leaders Exploring the Relevance of Spirituality in The Workplace. Management Decision, 45(2), 217-234. https://doi.org/10.1108/00251740710727250

Spencer, J. L. (2007). The New Frontier of Servant Leadership. In The Servant Leadership Research Roundtable. Regent University.

Van Meter, R., Chonko, L. B., Grisaffe, D. B., \& Goad, E. A. (2016). In Search of Clarity on Servant Leadership: Domain Specification and Reconceptualization. AMS Review, 6(1-2), 59-78. https://doi.org/10.1007/s13162-016-00752 
Walumbwa, F. O., Mayer, D. M., Wang, P., Wang, H., Workman, K., \& Christensen, A. L. (2011). Linking Ethical Leadership to Employee Performance: The Roles of LeaderMember Exchange, Self-Efficacy, and Organizational Identification. Organizational Behavior and Human Decision Processes, 115(2), 204-213. https://doi.org/10.1016/j. obhdp.2010.11.002

Wang, S., \& Noe, R. A. (2010). Knowledge Sharing: A Review and Directions for Future Research. Human Resource Management Review, 20(2), 115-131. https://doi. org/10.1016/j.hrmr. 2009.10.001 